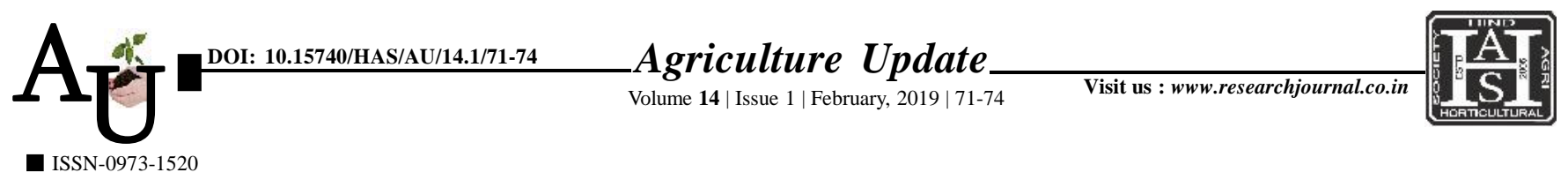

\title{
Resfarch Article: Gender participation and decision making patteren of farming families in dairy farming
}

Supriya P. Patil and Shobha Nagnur

Article Chronicle: Received :

29.11.2018;

Revised :

11.01.2019;

Accepted :

17.01.2019

KEY WoRds:

Dairy farming,

Gender participation, Decision making

Author for correspondence :

Supriya P. Patil

Department of Extension

and Communication

Management, College of

Community Science,

University of Agricultural

Sciences, Dharwad

(Karnataka) India

Email: sidjamanal@

gmail.com

See end of the article for

authors' affiliations
SUMMARY : India is an agriculture based country and livestock sector is an integral component for rural livelihoods. In India livestock production is largely in the hands of women constituting about 69 per cent of work force. Dairy occupation has been an age old practice because of its complementary nature with agriculture and the vegetarian food habits of most Indians. The study was conducted to know the gender participation and decision making pattern of farming families in dairy farming. The study was conducted in Dharwad, Belagavi, Bagalkote, Vijayapura, Gadag, Haveri and Uttar Kannada districts of Karnataka. Snowball sampling method was used to select the respondents who were engaged in crop + dairy enterprise. Eighty farming families were selected for the study. The study revealed that in regular activities like, processing of milk (88.80\%), selling the milk (81.20\%), milking $(80.00 \%)$ and putting the waste in bin $(67.50 \%)$ were dominated by women. Men dominated in the activities like, chaffing $(72.50 \%)$ and fodder transportation $(67.50 \%)$. Both men and women jointly participated in white washing of sheds $(91.20 \%)$, preparation of concentrate $(66.20 \%)$ and fodder harvesting and collection $(53.80 \%)$. In health activities, more men were involved in vaccination, taking the calf for dehorning and breeding (ranging from 83-55\%). Activities like care of sick animals (88.80\%) and care of new born (61.20\%) were carried out jointly. In marketing, more men participated in selling the skin of dead animals (78.80\%), purchasing of animals (70.00\%). More women were involved in selling the milk (78.80\%). In decision making pattern more men take decision about insurance of animals $(75.00 \%)$, breeding of animals (73.80\%), purchase of fodder (58.80\%) and feeding of animals (47.50\%). Most of the decisions like, pre and post-natal management (96.20\%), purchase and sale of animals $(85.00 \%)$, cattle shed management (81.20\%), obtaining bank loans (72.50\%) and fodder management $(55.00 \%)$ were taken by both men and women.

How to cite this article : Patil, Supriya P. and Nagnur, Shobha (2019). Gender participation and decision making patteren of farming families in dairy farming. Agric. Update, 14(1): 71-74; DOI : 10.15740/HAS/AU/14.1/71-74. Copyright@ 2019: Hind Agri-Horticultural Society. 